\title{
The Trace Element Content Observed in the Elderly People of Russia's North Regions
}

\author{
Lugovaya Elena, Maximov Arkadiy and Stepanova Evgenia \\ Scientific Research Center “Arktika” FEB RAS, Magadan 685000, Russia
}

Received: April 15, 2013 / Accepted: April 25, 2013 / Published: June 30, 2013.

\begin{abstract}
To investigate the status of mineral metabolism in people residing in huge regional centers of north-western and north-eastern parts of Russia by AES-IBP (atom-emission spectrometry with inductively bonded argon plasma), the content of 25 elements in hair samples of surveyed people was examined. The results of the study carried out in Russia's north could testify to significant deformation found in the elderly people bodies' element profiles. The pronounced deficit in such essential elements as Ca, $\mathrm{Cr}, \mathrm{Mg}$ can be considered the common north-related profile typical for the elderly people from European and Asian north. In addition, age-related formation of all the elements' deficit due to their risen spending at pathologies as well as the increased need in such elements as $\mathrm{Zn}, \mathrm{Se}, \mathrm{Cr}, \mathrm{Cu}, \mathrm{Mn}$. The age-related excess of arsenic proved to be typical for Magadan residents. In Anadyr, the age-related excess of lead was found, in Petrozavodsk - mercury, and in Arkhangelsk — boron and aluminium.
\end{abstract}

Key words: Macro- and micro-elements, elder people, northern regions of Russia.

\section{Introduction}

In the Russian Federation, as more as 16 administrative areas as well as some parts of another 11 areas have been referred as to the Extreme North territories or those being similar to them. The territories cover 11 million square kilometers that is almost two thirds of Russia's area. About 10.7 million people or $7.4 \%$ of all the country's population reside in these territories. Among them are representatives from 30 indigenous peoples that are small in numbers. The circumpolar territories on the globe's surface that are situated beyond the range of $65^{\circ}$ north and south latitudes are considered to be "high" latitudes.

There are some factors that negatively influence the demographical processes and health state of native residents. They are extremeness of the climate and environmental conditions, ecological "fragileness", one-sided economic structure of the northern regions that is based on extracting and processing of mostly

Corresponding author: Lugovaya Elena, biology candidate, associated professor, research fields: physiology, human adaptation, extreme conditions, macro- and trace elements, gerontology. E-mail: elena_plant@mail.ru. non-renewable resources, insufficient sophistication of social sphere including health care.

Anyway most diseases are connected with and often caused by the environment factors, which are well known regarding Russia's north. Low environmental temperatures, photoperiodicity, high level of the air ionization, sharp non-periodical tension fluctuations occurred in geomagnetic and static electric field, atmospheric pressure over-falls and lowered partial density of oxygen in the air are among them. The exposure of the body to these unfavourable factors can cause disorders in the main physiological systems and lead to pathologies. In addition, it is known that the most significant disorders usually occur in respiratory, hematogenic and blood circulatory systems, as well as in immune, endocrine, reproductive and nervous systems. As regards the term of the "polar" metabolic type, it has been already formulated, while the "circumpolar" metabolic type is on the point of being ascertained soon [1-3].

It is known that high latitude conditions leads to changes in mineral metabolism [4-6]. That can be 
connected with a special chemical content of the local food products and their consumption patterns and, also, with the fact that there are biogeochemical provinces where the soils and waters are low in some trace elements and, as well, with peculiarities of the elements' metabolism in indigenous populations of the north, which has apparently been formed during the lives of the several generations.

It is known that macro- and micro-elements play a significant role in different physiological and pathological processes. They intensively influence the body growth and development, the processes of hematosis, endocrine, nervous, cardiovascular and digestive functions and metabolic processes with proteins, carbohydrates, fats, vitamins and mineral substrates, as well as the processes of immunity, antibodies formation and increase of the organism's resistance to virulent diseases.

The fact is that both elderly people and children can demonstrate health disorders typical for the region since they have resided for a long time under conditions of tension observed in the body organs and systems. Such tension causes exhaustion in the adaptation reserves and, moreover, not only classic age-related diseases, but also region-related ones like element misbalance. Having taken these aspects into account, the authors aimed the study at exploring the peculiarities of the elemental systems of the elderly people residing in different northern regions of Russia.

\section{Materials and Methods}

To study the status of mineral metabolism, the authors examined people residing in big regional centers of Russia's northwest and northeast. The method of AES-IBP (atom-emission spectrometry with inductively bonded argon plasma) was used and applied on the Optima 2000 DV unit (Perkin Elmer, USA) in the "Centre of Biotic Medicine" where we examined the content of 25 elements in the hair samples taken from the examined subjects (Al, As, B, $\mathrm{Be}, \mathrm{Ca}, \mathrm{Cd}, \mathrm{Co}, \mathrm{Cr}, \mathrm{Cu}, \mathrm{Fe}, \mathrm{Hg}, \mathrm{I}, \mathrm{K}, \mathrm{Li}, \mathrm{Mg}, \mathrm{Mn}, \mathrm{Na}$, $\mathrm{Ni}, \mathrm{P}, \mathrm{Pb}, \mathrm{Se}, \mathrm{Si}, \mathrm{Sn}, \mathrm{V}, \mathrm{Zn}$ ) (Table 1).

The hair element concentration data calculated by specialists of CBM for the central regions of Russia were used as the baseline indices [7].

To statistically express the element concentration levels as the average index, standard deviation and median, as it is often used in scientific studies, seems to be less informative with the regard to the materials intended for wide practical usage, where the number of deviations from the normal level towards greater or less indices could be presented in percents. Disorders in the bioelement concentration are presented in the form of the element misbalance formulas, based on the frequency of the elemental excess or deficiency revealed in more than $50 \%$ of the total number of the examined people in each group.

\section{Results and Discussion}

The results of the study carried out in Russia's north could testify to significant deformation found in the elderly people bodies' element profiles.

Of note that $93 \%$ of the male residents of Petrozavodsk city demonstrated the pronounced deficit in $\mathrm{Mg}, 86 \%$ of them in $\mathrm{Ca}$ and $\mathrm{Co}, 57 \%-\mathrm{Fe}$, $50 \%-\mathrm{Zn}, 43 \%$ - I, and $36 \%$ experienced lack in $\mathrm{Cu}$. As regards the females of the mentioned city, their hair samples were also analyzed and $84 \%$ of them had deficit of Co, $76 \%-\mathrm{Zn}, 71 \%-\mathrm{Ca}, 64 \%-\mathrm{I}, 56 \%$

Table 1 Sex-age structure of surveyed people residing in Russia's north regions.

\begin{tabular}{lllllll}
\hline & & \multicolumn{2}{c}{ Russia's northwest } & & \multicolumn{2}{c}{ Russia's northeast } \\
\cline { 3 - 4 } Men & Petrozavodsk & Arkhangelsk & & Magadan & Anadyr \\
\hline \multirow{2}{*}{ Women } & Number of surveyed $(n)$ & 15 & No data & & 25 & 15 \\
& Average age, years $(M \pm m)$ & $73.86 \pm 2.25$ & No data & & $61.58 \pm 1.40$ & $57.85 \pm 1.47$ \\
\hline & Number of surveyed $(n)$ & 45 & 25 & & 100 & 15 \\
& Average age, years $(M \pm m)$ & $70.22 \pm 1.30$ & $87 \pm 0.98$ & & $64.27 \pm 1.03$ & $58.38 \pm 1.60$ \\
\hline
\end{tabular}


$\mathrm{Mg}, 51 \%-\mathrm{Fe}, 49 \%-\mathrm{P}$, and $42 \%-\mathrm{Cu}$. About half of the examined male subjects showed excess in K. As for the female subjects, $64 \%$ and $62 \%$ of them were high in $\mathrm{Na}$ and $\mathrm{K}$, respectively.

In the female residents of Arkhangelsk city, a great number of occasions with exceeded concentrations were revealed: K (56\%), Na (48\%), Zn (32\%), P (24\%) and, on the contrary, the pronounced deficit of Co (100\%), $\mathrm{Ca}(96 \%), \mathrm{Cu}(92 \%), \mathrm{Mg}(68 \%)$ and $\mathrm{Fe}$ $(32 \%)$.

In the group from Magadan city, the moderate and pronounced element changes were the following: deficit was demonstrated by the male subjects in $\mathrm{Mg}$ (46\%), $\mathrm{Ca}$ and $\mathrm{Cr}(38 \%)$, and by the female subjects in Co (59\%), Mg (57\%), Ca (56\%), I (48\%), Cu (41\%), $\mathrm{Zn}(37 \%)$, and $\mathrm{Fe}(35 \%)$; excess was observed in the hair samples taken from the male subjects in $\mathrm{Na}$ $(38 \%), \mathrm{K}(33 \%)$, and from the female subjects-in $\mathrm{Na}$ (53\%), Si (46\%) and K (35\%).

The examination of the residents of the city of Anadyr resulted in the following findings: the females demonstrated more expressed misbalance in the body element system as compared to the males of the examined region. The latter showed deficit of $\mathrm{Co}$ in $85 \%, \mathrm{Fe}$ in $77 \%, \mathrm{Cu}$ in $62 \%, \mathrm{Ca}$ in $46 \%, \mathrm{Mg}$ in $23 \%$ and, they demonstrated excess in $\mathrm{Zn}$ and $\mathrm{P}$ (in $62 \%$ and $31 \%$ of the subjects, respectively). At the same time, the females, in $100 \%$ and $94 \%$ showed excess in $\mathrm{Na}$ and K, respectively. However, they proved to have significant deficit in such essential bioelements as $\mathrm{Mg}$ in $81 \%$ of all the occasions, $\mathrm{Ca}$ and $\mathrm{Co}$ in $75 \%, \mathrm{Cu}$ in $69 \%, \mathrm{Zn}$ in $50 \%$ and $\mathrm{Mn}$ in $25 \%$.

The content of some elements (Al, As, B, Cd, Hg, $\mathrm{Li}, \mathrm{Ni}, \mathrm{Pb}, \mathrm{Se}, \mathrm{Sn}, \mathrm{V})$ in the hair samples could be considered as territory-dependent. Of note that, $24 \%$ of the females and $21 \%$ of the male subjects in the city of Petrozavodsk were high in $\mathrm{Hg}$. Such deviation was not typical for the residents of the other regions. Single occasions of the excess were found in $\mathrm{B}, \mathrm{Cd}$, and $\mathrm{Hg}$ among the male subjects and, in $\mathrm{B}, \mathrm{Li}, \mathrm{Pb}$, and $\mathrm{Sn}$ - among the female ones. The hair samples from
Arkhangelsk city testified to the excess in $\mathrm{B}$ and $\mathrm{Al}$ experienced by $32 \%$ and $12 \%$ of the examined women, respectively. That can be apparently explained by the fact that Arkhangelsk region is one of Russia's areas where the water objects used as water supply are much polluted [8]. In the group of Magadan examinees, $33 \%$ of all the men and $12 \%$ of the women showed significant excess in As, which could be caused by either mineral water intake or, apparently, by disorders in regulation of phosphorus metabolism. Besides, the hair samples taken from those male subjects proved to be high in $\mathrm{Pb}$ in $17 \%$ of the occasions. Single findings of excess were revealed in $\mathrm{Al}, \mathrm{Cd}, \mathrm{Li}, \mathrm{Sn}$ and $\mathrm{V}$ among the males and, in $\mathrm{Al}, \mathrm{B}$, $\mathrm{Cd}, \mathrm{Hg}, \mathrm{Li}, \mathrm{Ni}, \mathrm{Pb}$ and $\mathrm{V}$ among the females. In the group of Anadyr examinees, rare occasions of exceeded indices were observed in $\mathrm{Cd}, \mathrm{Pb}, \mathrm{Hg}$ and $\mathrm{B}$ in the males and, in $\mathrm{Pb}, \mathrm{Hg}$, $\mathrm{Ni}$ and $\mathrm{Li}$ in the females.

In general, the element disorders demonstrated by the examined populations are presented in Fig. 1.

Thus, the pronounced deficit in such essential elements as $\mathrm{Ca}, \mathrm{Cr}, \mathrm{Mg}$ can be considered the common north-related profile typical for the elderly people from European and Asian north. In addition, the age-related deficit of all the elements caused by their higher expenses at pathologies as well as the increased need in such essentials as $\mathrm{Zn}, \mathrm{Se}, \mathrm{Cr}, \mathrm{Cu}$, Mn playing an important role in antioxidant and immune activities, in maintaining the process of bone mineralization $(\mathrm{Cu}, \mathrm{Mn})$ and regulating carbohydrate and fat metabolism $(\mathrm{Cr}, \mathrm{Mn}, \mathrm{Cu})$ can be considered the element system profiles typical for the residents of Russia's northern regions [9]. The age-related excess of arsenic proved to be common for Magadan residents. That fact was also mentioned in the earlier references [10]. In Anadyr, the study found the age-related excess of lead; in Petrozavodsk, the indices were high in mercury, and in Arkhangelsk-in boron and aluminium. Accumulation of heavy or toxic elements in people as they age can happen due to weakening of the process of their elimination from the 

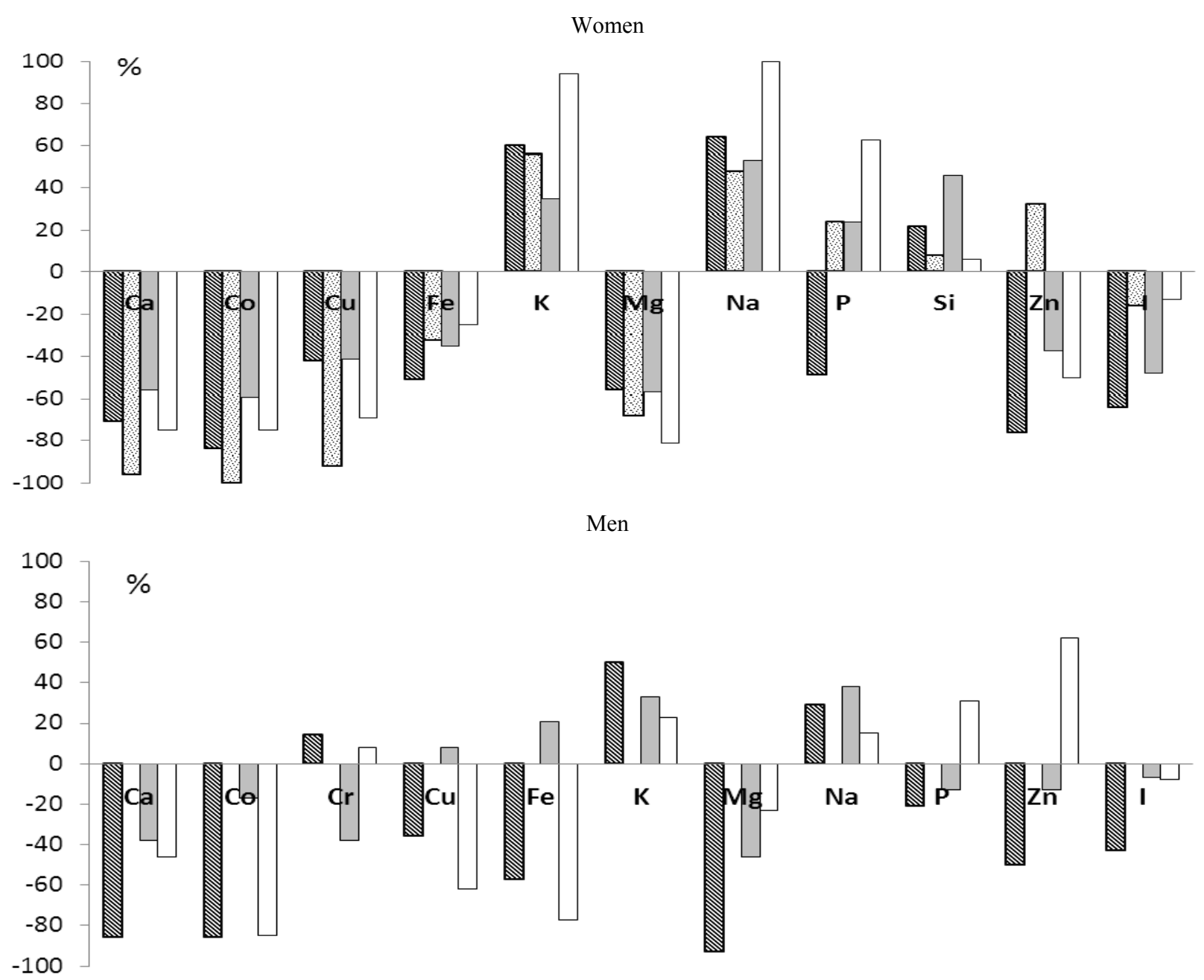

$\mathbb{\mathbb { N }}$ Petrozavodsk $\quad$ Arkhangelsk $\square$ Magadan $\square$ Anadyr

Fig. 1 The deviation rates in the bioelement mean concentrations observed in the hair samples of the elderly people of Russia's north regions with the normal indices.

body while the specifics of the element is associated with biogeochemical profiles of the residing area. On the other hand, the excess of these elements is, apparently, a defensive mechanism that prevents from formation of atypical cells.

\section{Conclusion}

Thus, as it turned out from the carried studies, the residents of different northern regions of the similar age, sex and lifestyle demonstrate their specific mineral metabolism that significantly differs from the commonly approved physiological norms. Apparently, the endogen factors associated with the age-related changes in the body functional systems have become those very things that play the leading role in the formation of microelement misbalance in the elderly people under modern social conditions. At the same time, the natural-climatic extremes, acting by synergy principle, potentiate and consolidate negative processes occurred in the body.

\section{References}

[1] N.V. Dorshakova, T.A. Karapetyan, Living in the North, Online Magazine «Lyceum», 2012, available at: http://www.gazeta-licey.ru/science/natural-and-mathemat ical-sciences/item/4037-zhit-na-severe.

[2] V.P. Kaznacheyev, Human Adaptive Strategy in High Latitude, Leningrad, Russia, 1980, p. 199.

[3] L.E. Panin, Homeostasis and problems of circumpolar 
medicine (methodological aspects of adaptation), Bulletin of SB RAMS 30 (3) (2010) 6-11.

[4] A.P. Avtsyn, A.A. Zhavoronkov, A.G. Marachev, A.P. Milovanov, Human Pathology in the North, Moscow, Russia, 1985, p. 416.

[5] I.A. Alekseyeva, S.A. Hotimchenko, M.A. Stepchuk, B.P. Sukhanov, On the question about the status of mineral metabolism in indigenous and alien population residing in the regions of the Far North, Occupational Medicine and Industrial Ecology 6 (1996) 43-46.

[6] A.L. Maximov, E.A. Lugovaya, Comparative evaluation of elemental status in girl-aborigines residing in different regions of north-east of Russia, Human Ecology 7 (2010) 30-35.

[7] A.V. Skalny, Ecological and physiological grounds for efficiency of applying micro- and macroelements at homeostasis disorders in subjects of different climatic and geographical regions, Diss. Med. Doctoral, 2000, p. 361.

[8] About sanity and epidemiological welfare of population in Russian Federation in 2011: State report-M.: Federal Hygiene and Epidemiology Centre of Federal Service for Oversight of Consumer Protection and Welfare, Moscow, Russia, 2012, p. 316.

[9] A.V. Skalny, Materials of the III research and practice conference of the "Health Spring" program members, Russia, 2002, p. 48.

[10] E.A. Lugovaya, A.L. Gorbachev, A.V. Efimova, Age-related alteration of elements status of Magadan residents, Advances in Gerontology 12 (2003) 103-110. 